\title{
Piercing Proverbial Crows' Eyes: Theft and Publication in Renaissance France
}

\author{
EMMA HERDMAN
}

University of St. Andrews

The ironic Latin proverb "cornicum oculos configere" was classically illustrated by the example of Gnaeus Flavius, celebrated for his theft and valuable but unauthorized publication of Rome's legal secrets. Erasmus's discussion of the proverb in the Adages consequently focuses on the tension within the transfer of knowledge between openness and secrecy, and on the fragile status of intellectual authority within a scholarly domain made increasingly public by the printing press. This article uses the example of Flavius to trace the idea of theft within Renaissance attitudes to the possession and dissemination of knowledge. It compares the reception of Flavius in three contexts: Erasmus's ambivalence towards publication as a form of theft in the Adages; ancient criticisms of theft as social presumption; and the more positive representation of epistemological theft in the works of four Renaissance French jurists. It thus argues that Erasmus represents a turning point both in the reception history of Flavius and in attitudes to intellectual theft-and thereby to intellectual property-in the Renaissance.

Pour illustrer le proverbe latin ironique "cornicum oculos configere ", les classiques avaient recours à l'exemple de Gnaeus Flavius, célébré pour le vol et la publication, utile mais non-autorisée, des secrets juridiques de Rome. La discussion de proverbe par Érasme dans les Adages tourne autour de la tension qui caractérise le transfert du savoir, entre ouverture et secret; elle évoque également la fragilitédu statut conféréà l'autorité intellectuelle au sein des publications savantes, quel'imprimerie rendait de plus en plus publiques. Cet article s'appuie sur l'exemple de Flavius pour comprendre les attitudes adoptées à la Renaissance à l'égard du vol, de la possession et de la dissémination du savoir. Il compare la réception de Flavius dans trois contextes: l'ambivalence d'Érasme envers la publication conçue comme une forme de vol dans les Adages; les critiques anciennes du vol comme transgression sociale; enfin, la représentation plus positive du vol épistémologique chez quatre juristes français de la Renaissance. Il soutient ainsi qu'avec Érasme, se clôt un chapitre de l'histoire de la réception de Flavius tandis qu'à la Renaissance, la perception du vol intellectuel - et donc de la propriété intellectuelle - se transforme.

\section{Frasmus's commentary in the Adages on the classical proverb "cornicum Coculos configere" (to pierce the crows' eyes) opens with a famous example of valuable but unauthorized publication brought about by an enterprising theft. ${ }^{1}$ In a seminal moment in Roman legal history, a clerk called Gnaeus}

1. Erasmus, Adage 275: see Adagiorum chilias prima, ed. M. L. van Poll-van de Lisdonk and others, in Opera omnia Desiderii Erasmi Roterodami (Amsterdam: North-Holland, 1969-94; Amsterdam: Elsevier, 
Flavius uncovered the secrets behind the operation of the law, to which only the pontiffs had privileged access, and published them for the public good. ${ }^{2}$ The story of Flavius's theft, as told by Sextus Pomponius, is recorded in the opening pages of the emperor Justinian's Digest of Roman law:

Postea cum Appius Claudius proposuisset et ad formam redegisset has actiones, Gnaeus Flavius scriba eius libertini filius subreptum librum populo tradidit, et adeo gratum fuit id munus populo, ut tribunus plebis fieret et senator et aedilis curulis. hic liber, qui actiones continet, appellatur ius civile Flavianum, sicut ille ius civile Papirianum: nam nec Gnaeus Flavius de suo quicquam adiecit libro. ${ }^{3}$

Pomponius's narrative celebrates Flavius, defending his theft and publication as beneficial to the public, emphasizing his editorial fidelity and discretion, and justifying his reward. This is one of ten ancient versions of events; while the sources are far from unanimous in praising Flavius for his assault upon hierarchical privilege and power, the inclusion of Pomponius's account within

1994-97; Leiden: Brill, 1997-), hereafter cited as ASD, 2.1 (1993): 380-82; see also Adages I.i.1 to I.v.100, trans. Margaret Mann Phillips, annot. R. A. B. Mynors, in Collected Works of Erasmus (Toronto: University of Toronto Press, 1974 - ), hereafter cited as CWE, 31 (1982): 295-97. Ampersands have been resolved and modern distinctions drawn between $i$ and $j$, and between $u$ and $v$, in all quotations from Latin texts. I should like to thank two anonymous readers for Renaissance and Reformation for their extremely helpful comments and suggestions; I am particularly grateful to Peta Fowler for her help with Renaissance Latin and for introducing me to Flavius.

2. On Flavius, to whom the thefts of either or both the calendar and the ius civile (containing the formulae for legal actions) are variously attributed, see Simon Hornblower and Antony Spawforth, eds., The Oxford Classical Dictionary (Oxford: Oxford University Press, 1996), s.v. "Flavius, Gnaeus." Fritz Schulz, in History of Roman Legal Science (Oxford: Clarendon Press, 1946), 9-10, sceptically notes: "sensational events have no place in the history of Roman legal science" (10); see also S. P. Oakley, A Commentary on Livy Books VI-X, 4 vols. (Oxford: Clarendon Press, 2005), 3:600-15.

3. "Thereafter, when Appius Claudius had written out these actions-at-law and brought them back into a common form, his clerk Gnaeus Flavius, the son of a freedman, pirated the book and passed it over to the people at large. This service so ingratiated him with the citizenry that he became a tribune of the plebs, a senator and a curule aedile. The book which contains the actions-at-law is called The Flavian Civil Law on the same basis as the above-mentioned The Papirian Civil Law, for neither did Gnaeus Flavius put a word of his own into the book." In The Digest of Justinian, 1.2.2.7, ed. Theodor Mommsen and Paul Krueger, trans. Alan Watson, 4 vols. (Philadelphia: University of Pennsylvania Press, 1985), $1:[$ unpaginated]. 
the Digest helps cement Flavius's much-romanticized reputation as a Republican hero, who selflessly acts for the public good.

Erasmus's reference to Flavius, who takes privileged information from the private preserve of the pontiffs and places it in the public domain, is thus to an exemplary symbol of the humanist project, which wrests valuable knowledge from the exclusive possession of Antiquity and places it, through publication, within an intellectual commonwealth. Such a commonwealth has no place for the private possession of knowledge or the withholding of information; as Kathy Eden has shown, the Adages demonstrates Erasmus's conception of the res litteraria as public property, not to be appropriated but to be shared between friends. ${ }^{4}$ This indicates a notable difference between ancient and Renaissance attitudes to publication, in that even the most enthusiastic of the classical accounts present Flavius's actions as a form of theft. ${ }^{5}$ In contrast, the Renaissance conception of a commonwealth of knowledge seems to preclude the possibility of theft, since it rules out any claim to private possession of information: the emerging concept of "intellectual property" (avant la lettre) relates more to credit, or to the possession of a good reputation, than to ownership rights over the written word. ${ }^{6}$

Yet the idea of theft, which tests the legitimate limits of the acquisition, possession, and transmission of knowledge, nevertheless lies behind humanists'

4. Kathy Eden, Friends Hold All Things in Common: Tradition, Intellectual Property, and the Adages of Erasmus (New Haven and London: Yale University Press, 2001), dx.doi.org/10.12987/yale/ 9780300087574.001 .0001 .

5. Theft is apparent in the main verb employed in each account: compilare (to plunder, pillage, rob) in Cicero; subripere (to take away secretly; to steal, pilfer, purloin) in Pomponius; excipere (to withdraw; to catch, capture; to intercept) in Pliny. See Charlton T. Lewis and Charles Short, A Latin Dictionary (Oxford: Clarendon Press, 1879; repr. 2002), s.vv. “compilo," “excipio," and “surripio." For full references to the accounts by Cicero and Pliny, see the further discussion of them below.

6. On the Renaissance distinction between plagiarism, or literary theft of credit, and ownership, or the emerging concept of intellectual property, see Pamela O. Long, Openness, Secrecy, Authorship: Technical Arts and the Culture of Knowledge from Antiquity to the Renaissance (Baltimore: Johns Hopkins University Press, 2001), 10-12. Long argues that “the concept of 'intellectual property' developed in the context of the medieval craft guild, centuries before the emergence of the modern legal terminology that describes it" (Long, 5). On the gradual conflation of these two ideas, see the discussion of Horace's proverbial image of the crow in borrowed feathers, representing the imitative poet both adorned with another's verses (intellectual property) and usurping unmerited praise (literary theft of credit), in Eric M. MacPhail, Dancing around the Well: The Circulation of Commonplaces in Renaissance Humanism (Leiden: Brill, 2014), 23, dx.doi.org/10.1163/9789004277151. 
epistemological anxieties, particularly within the Renaissance context of a nascent and unregulated printing industry. For while the ideal of an intellectual republic, offering open access to freely circulating information, is clearly served by the availability of printing, it does not benefit from an unqualified licence to print; a flood of unfiltered publications does as much damage to the commonwealth as the withholding of valuable information, as Erasmus's discussion of printing in his commentary on "festina lente" (make haste slowly) reveals. ${ }^{7}$ Erasmus construes only the damaging of literary reputation explicitly as a theft, yet his discussion sows the seeds for the withholding of information to be considered as a form of theft as well. Erasmus thus heralds a subtle change in Renaissance conceptions of theft and ownership-a change that is reflected in and illustrated by the changing representations of Flavius and of his publication and theft.

This article uses the example of Flavius to trace the emergence and development of the idea of theft-present in Antiquity-within Renaissance attitudes to knowledge (or to intellectual property) and to publication (with the epistemological concerns it raises). It compares the reception of Flavius's theft and publication in three different contexts. First, it analyzes the place of theft within Erasmus's ambivalence towards publication as set out in the Adages. His commentary on "festina lente" draws an explicit analogy between theft and publication, while his commentary on "cornicum oculos configere" juxtaposes Flavius with increasingly critical representations of thieves and of modernizers who similarly take and publish the knowledge of the Ancients. Next, it contrasts the primarily epistemological grounds for Erasmus's ambivalence towards theft and publication with the largely sociological grounds, based on respect for social and religious hierarchies, for ancient criticism of Flavius. Finally, it argues that Erasmus's epistemological reading of Flavius's theft influences the generally more positive representations of Flavius found in the Renaissance. Taking its examples from the works of four Renaissance French jurists, Guillaume Budé, Claude Mignault, Pierre Coustau, and Pierre de La Place-each perhaps favourably predisposed to Flavius by their familiarity with Justinian's Digest-it demonstrates the increasingly unambiguous celebration of this model for unauthorized publication and theft. By focusing 
on the emergence and development of the idea of epistemological theft, this article thus highlights the corresponding shift in Renaissance conceptions of intellectual ownership, made suddenly precarious by the advent of printing. For all that the example of Flavius may promote the idea of theft as a metaphor for the transfer of knowledge, it does little to dispel humanist anxieties about the role and regulation of the printing press.

\section{"Festina lente": Erasmus on publication as theft}

Erasmus's discussion of printing, in his commentary on "festina lente," reveals his misgivings about the lack of regulation governing a still nascent industry and reflects the tension between the ideas of epistemological openness and restraint. ${ }^{8}$ In defence of openness, the publication of scholarly editions of important texts is invaluable to the humanist project, which was commendably served by exemplary printers such as Aldo Manuzio, who published the 1508 edition of the Adages and who had adopted "festina lente," symbolized by the image of a dolphin coiled around an anchor, as his printer's mark. ${ }^{9}$ Erasmus praises Aldo for his contributions both to the fabric of the res literaria, through the high quality of his publications that restore the learning of Antiquity and build a "bibliothecam [...], cuius non alia septa sint quam ipsius orbis", and to its spirit, through the generosity and openness with which Aldo shares information and resources with his collaborators. ${ }^{10}$ This open attitude to sharing and publishing information is essential to a commonwealth of knowledge. In sharp contrast, the unnamed friend who refused to lend a particularly helpful volume to Erasmus while he was compiling the Adages represents a fear that opening access to knowledge will lead to the loss of public admiration for the erudition of scholars. ${ }^{11}$ This misplaced desire to possess a monopoly over

8. Erasmus, Adage 1001, ASD, 2.3:7-28; CWE, 33:3-17.

9. See CWE, 33:340n17.

10. "A library which knows no walls save those of the world itself." Erasmus, Adage 1001, ASD, 2.3:18; CWE, 33:10. On the Adages itself as a universal library, see MacPhail, 116-33. On openness within the crafts in the Renaissance, see Long.

11. Erasmus, Adage 1001, ASD, 2.3:24; CWE, 33:15. On reasons behind the traditional refusal to divulge scholarly secrets to an unworthy public, see William Eamon, Science and the Secrets of Nature: Books of Secrets in Medieval and Early Modern Culture (Princeton: Princeton University Press, 1994), 3-90. 
knowledge is entirely at odds with Erasmus's aim in the Adages to bring ancient wisdom accessibly into the public domain. ${ }^{12}$

Yet openness that leads to a proliferation of poor-quality publications does as much damage to the scholarly enterprise as the withholding of information, and it brings printing into disrepute. Not every printer is an Aldo, and the absence of regulation means that nothing prohibits practitioners who are "literarum ignari," "ignavi," or "sordidi" from flooding the market with shoddy editions of inferior works. ${ }^{13}$ Erasmus's objection is that this outpouring of publications damages the body of knowledge (unreliable editions add further errors to, rather than emending, corrupt texts), the acquisition of knowledge (a sea of unworthy publications drowns out scholarly editions and offers readers distraction from valuable intellectual pursuits), and the status of knowledge (the unreliability of such editions devalues the printed word and diminishes intellectual authority). ${ }^{14}$ The editorial tasks of filtering information and of identifying and authorizing scholarly value are thus taken from the skilled hands of an Aldo or an Erasmus and entrusted directly to the unqualified reading public.

Erasmus regrets this loss of quality control; he praises the secretive practices of the ancient Egyptian theologians, "qui nefas esse ducebant sapientiae mysteria literis communibus vulgo prophano prodere, quemadmodum nos facimus," and so used hieroglyphics to preserve the exclusivity of their knowledge. ${ }^{15}$ Similarly, in the Ratio verae theologiae, Erasmus emphasizes the value of the allegories and parables that veil the meaning of the scriptures; the reader who wishes to penetrate such hidden meanings may benefit from linguistic skill and from a good hermeneutic guide, but chiefly needs a pure heart and mind. ${ }^{16}$ This sense that access to the scriptures should be promoted but that not all are qualified to read or interpret them correctly is at the heart of Erasmus's debate with Luther over the hermeneutic intentions of New Testament scholarship. ${ }^{17}$

12. Eden, Friends Hold All Things in Common, 143.

13. The "ill-educated," “idle," or "mercenary." Erasmus, Adage 1001, ASD, 2.3:18; CWE, 33:11.

14. Erasmus, Adage 1001, ASD, 2.3:18-20; CWE, 33:11-12.

15. "Who thought it quite wrong to express the mysteries of wisdom in ordinary writing and thus expose them, as we do, to the uninitiated public." Erasmus, Adage 1001, ASD, 2.3:11-12; CWE, 33:6.

16. Erasmus, Ratio seu methodus compendio perveniendi ad veram theologiam, trans. Robert D. Sider, in CWE, 41 (2019), 632-33 and 636 (on hidden allegories); 693-700 (on the limits of human understanding); 489-96 (on the criteria for the qualified reader).

17. For a summary of this debate, see Robert D. Sider, "General Introduction," in CWE, 41:261-64. 
Respect for the Egyptians' reverent refusal to profane divine wisdom by placing it openly before a diversely qualified public becomes the standard humanist position in the Renaissance; Egyptian hieroglyphics act as a filter that preserves divine mystery from unworthy readers while nevertheless making it selectively accessible to those with the time, patience, and learning to understand what they contain. ${ }^{18}$ Erasmus thus rejects the indiscriminate publication of his own day as a mark of "barbara ista pinguique doctrina," and adopts instead a more selective approach. ${ }^{19}$ The Adages may expose scholarly mysteries, but it is limited to a readership with a sufficient degree of education and wealth to access a printed book in Latin; initiation into the meaning of Egyptian hieroglyphics, such as the symbol of the dolphin and anchor, is thus filtered. ${ }^{20}$

Erasmus's call for regulation of the printing industry is thus based upon epistemological concerns, expressed in terms of value, which require a delicate balance to be struck between openness and secrecy. Both have their drawbacks: the publishing of information is admirable in an Aldo but damaging in common, less scrupulous printers; equally, the withholding of information, which seems ignoble in a scholar whose ambitions are selfish rather than public-spirited, finds a worthier counterpart in the reverent mysteriousness of the ancient Egyptians. Careful distinction is thus required: not all information belongs in the public domain, and not everyone has the right to put it there.

Behind these pragmatic questions of information management-or of who is qualified to publish-lies the idea of intellectual property. It appears most explicitly in Erasmus's comparison between the criminal fraudulence of mercenary printers, who profit from publishing misrepresentative or falsely attributed works, and that of the "fur, impostor, aut leno"-whose secret attacks upon an individual's purse do less damage than printers' open attacks upon a literary reputation, devaluing it in a particularly pernicious form of theft. ${ }^{21}$ Prior to copyright, the printing of a work instantly places it within the public

18. See Florence Vuilleumier Laurens, L'Université, la robe et la librairie à Paris: Claude Mignault et le "Syntagma de Symbolis" (1571-1602) (Geneva: Droz, 2017), 120; on Erasmus's own "erudita perspicuitas," or the filtering of his readership to provide clarity only for initiates, see MacPhail, 106.

19. "Barbarous and uncouth learning." Erasmus, Adage 1001, ASD, 2.3:16; CWE, 33:9.

20. Erasmus, Adage 1001, ASD, 2.3:12; CWE, 33:6.

21. "Any thief, any confidence-trickster, the keeper of any brothel." Erasmus, Adage 1001, ASD, 2.3:20; CWE, 33:13. Shakespeare's Iago, comparing the stealing of a purse with the filching of a good name (Othello, 3.3), would agree. 
domain; authors retain the right to claim ownership only of the credit due to them for works thus belonging to the literary commonwealth. ${ }^{22}$ Yet Erasmus's analogy shows that this context of an intellectual commonwealth does not eliminate the possibility of theft, which may be extended to the other aspects of publication mentioned in his discussion. What is the status of those who withhold information: do they legitimately keep secrets, or do they fraudulently lay private claim to (and so steal) what ought to belong to the commonwealth? Equally, what is the status of those who reveal privileged information? Does the unauthorized publication of secrets, extracted from the possession of private individuals, constitute a form of theft, or is it the just restoration of hidden (stolen) knowledge to the public domain where it belongs?

Erasmus's well-known discussion of printing in "festina lente" thus turns from anxiety over publication as devaluation to anxiety over publication as theft. Less well known is his application of these same ideas of theft and publication to a specifically epistemological context in his commentary on "cornicum oculos configere," which hinges on the respective status of ancient authorities and of modernizers who aim to update and surpass ancient wisdom. Erasmus's discussion of the proverb opens with the example of Flavius's theft and goes on to raise wider questions about intellectual ownership. Who (or what) is a proper repository for knowledge? What are the necessary qualifications for authoritative publication, and how can these be guaranteed? Can open access, leading to an unrestricted increase in would-be scholars, be reconciled with quality control? And is publication always desirable, or should some secrets legitimately be withheld? These concerns are at the heart of Renaissance humanists' anxieties about both the legitimacy of granting or limiting access to knowledge and the establishment of their own credentials as commentators on learned texts.

\section{"Cornicum oculos configere": Erasmus on theft as a metaphor for the transfer of knowledge}

The classical proverb "cornicum oculos configere" (to pierce the crows' eyes) refers to the use of the crows' technique-of attacking their prey first in the 
eye-to beat them at their own game. ${ }^{23}$ It thus celebrates, and enjoys the irony of, a victory over a sharp-sighted, cautious enemy. Yet the violence of the image, combined with the proverb's imputation of cunning, questions whether such a triumph should be hailed as a form of poetic justice or seen as a proliferation of vice (corvid cunning and cruelty). ${ }^{24}$ Accordingly, the proverb is also applied with irony, as Erasmus-who admits he struggled to find satisfactory authority for its precise meaning - points out. ${ }^{25}$ Through irony, the proverb questions the status not only of the crows from whom sight or knowledge is taken, but also of those who take it-and even of the stolen knowledge itself.

This irony is apparent in two contrasting examples of the proverb being applied to Erasmus himself. The first comes from The Praise of Folly, as Follyan assiduous reader of the Adages-makes one of her few references to its author: "Sed interim obstrepunt mihi Graeculi quidam, qui tot huius temporis theologorum ceu cornicum oculos student configere, dum annotationes suas veluti fumos quosdam aliis offundunt, cuius gregis si non Alpha, certe Beta meus est Erasmus, quem ego saepius honoris causa nomino."26 The claim that Erasmus's theological commentaries surpass those of the theologians is couched in a tone of fond (self-)deprecation as Folly cites the theologians' punning contempt for pedants who seek to displace their learning: "Neque

23. See Lewis and Short, s.v. "cornix," with the suggested English equivalent "to catch a weasel asleep." Configere can mean to fasten or to nail together, to pierce through, or to transfix; all these senses connote sharpness and blinding, through the joining of eyelids or the transfixing of a gaze: see Lewis and Short, s.v. "configo."

24. On the attribution of cunning both to crows themselves and to those who deceive them, see A. Otto, Die Sprichwörter und Sprichwörterlichen Redensarten des Römer (Leipzig: Teubner, 1890), 93.

25. "Effertur autem per ironiam" (It is uttered in irony): Adage 275, ASD, 2.1:381; CWE, 31:296. On Erasmus's difficulty with the proverb, see R. A. B. Mynors's note in CWE, 31:295.

26. "But at this point I hear an outcry from certain Greek pedants who are bent on pecking crows' eyes, or rather, catching out the many theologians of today by blinding them with the smokescreen of their own commentaries. The second place in this flock, if not the actual leadership, certainly belongs to my friend Erasmus, whom I mention by name from time to time by way of a compliment." Erasmus, Moriae Encomium, id est Stultitiae Laus, ed. Clarence H. Miller, in ASD, 4.3 (1979), 182; Praise of Folly, trans. Betty Radice, ed. A. H. T. Levi, in CWE, 27 (1986), 144. This passage forms part of a long insertion added to Matthias Schürer's edition of the Moriae Encomium, published in Strasbourg in November 1514, by which time Erasmus was fully engaged in writing biblical commentaries: see ASD, 4.3:30 and 183 . 
quisquam illorum Graeculos istos pluris facit quam Graculos." ${ }^{27}$ The diminutive presentation of Erasmus as a little Greek-speaking jackdaw, whose pedantry earns him Folly's friendship even as it corrects her biblical exegesis, reflects his ambivalence towards a proverb paradoxically endorsed, along with his scholarship and Erasmus himself, by praise from Folly. For while Folly uses the proverb to praise scholarship, Edward Lee, also a reader of the Adages, uses it to criticize intellectual presumption. In his letter of 1 February 1520 to Erasmus, Lee denies that his Annotationes seeks to correct Erasmus's New Testament scholarship, but suggests that Erasmus himself has no such qualms: "Ego te docebo, qui omnes veluti cum imperio doces, et cornicum, quod dicitur, oculos configis?"28 Lee's overtly modest and respectful deference to Erasmus's learning masks a more critical stance beneath the ambiguity of a proverb that may be used equally to praise or to blame.

The ambiguity of this ironic proverb is increasingly apparent in the four examples of its use that illustrate Erasmus's commentary on "cornicum oculos configere" in the Adages. Two opening examples from Cicero introduce the idea of theft and lead Erasmus to describe the proverb's probable origin and meaning, which he links explicitly to the transfer of knowledge across successive generations. The next two examples, from Jerome and Macrobius, also relate to the transfer and status of knowledge, but demonstrate the proverb's irony, leading Erasmus to conclude with a moral warning that swerves away from celebration of the successful blinding of crows to celebration of their virtues instead. The opening examples from Cicero are added to the Adages in 1508: they are cited but not quoted in the Collectanea of 1500, and their subsequent inclusion constitutes an acknowledgement of the more positive application of the proverb and its association with theft. ${ }^{29}$ Nevertheless, the turn in Erasmus's argument back to the more negative examples originally quoted in the Collectanea indicates his caution concerning this proverbial example of like

27. "Not one of these thinks of your Greek pedants as more than jackdaws." Erasmus, Moriae Encomium, in ASD, 4.3:182; Praise of Folly, in CWE, 27:144-45.

28. "I put you right? - you who put everyone right in your masterful way, and are quite capable, as they say, of pecking the crows' eyes out." Edward Lee, letter 1061, in Opus Epistolarum Des. Erasmi Roterdami, ed. P. S. Allen, 12 vols. (Oxford: Clarendon Press, 1906-58), vol. 4 (1922), 162; trans. R. A. B. Mynors, in CWE, 7 (1987), 175.

29. Erasmus, Adagiorum collectanea, ed. Felix Heinimann and M. L. van Poll - van de Lisdonk, in ASD, 2.9 (2005), 54 . 
being used to conquer like, or of knowledge falling into the hands of thieves, however skilful they may be.

\section{Theft as poetic justice: Erasmus's Ciceronian crows}

The two examples from Cicero with which Erasmus opens his commentary employ the proverb in similar ways, but with very different degrees of irony. The first concerns Flavius, and comes from the speech defending the recently elected consul Murena against accusations of electoral fraud. Cicero's defence depends partly upon praising Murena's character (as a man of action) at the expense of jurists (as men of academic debate) such as Murena's unsuccessful rival in the election, Servius Sulpicius Rufus, speaking for the prosecution. In his dismissal of lawyers, Cicero emphasizes their loss of authority following Flavius's theft; his use of the proverb in this context establishes Flavius as its conventional illustration in Renaissance France:

M. Tullius in oratione pro Murena scribit ad hunc modum: Deinde, etiam si quid apud maiores nostros fuit in isto studio admirationis, id enunciatis vestris mysteriis totum est contemptum et abiectum. Posset agi lege necne pauci quondam sciebant; fastos enim vulgo non habebant. Erant in magna potentia qui consulebantur; a quibus etiam dies tanquam a Chaldaeis petebantur. Inventus est scriba quidam, Cn. Flavius, qui cornicum oculos confixerit et singulis diebus ediscendos fastos populo proposuerit et ab ipsis iureconsultis eorum sapientiam compilarit. Itaque irati illi, quod sunt veriti ne dierum ratione pervulgata et cognita sine sua opera lege posset agi, notas quasdam composuerunt ut omnibus in rebus ipsi interessent. ${ }^{30}$

30. "Cicero in his speech in defence of Murena writes thus: 'In the second place, if any awe attached to that profession in the time of our ancestors, it fell into utter contempt and was destroyed by the publication of your mysteries. In former times very few knew whether or not an action at law could be brought; for the calendar was not publicly known. Those who gave legal decisions had great power; they were asked to indicate the day on which a suit could be brought, as if they were Chaldaean astronomers. A clerk by name Gnaeus Flavius was found who pierced the crows' eyes and published the calendar, enabling the people to learn up which were court days, and plucked their wisdom from the learned counsel themselves. And so these men, enraged because they were afraid that lawsuits could be conducted without their assistance, once the proper days were published and made a matter of general knowledge, invented certain legal formulae that they might still have a part in every transaction." Erasmus, Adage 275, ASD, 2.1:380; CWE, 31:295-96. Cf. Cicero, Pro Murena, 11.25, trans. C. Macdonald (Cambridge, 
Cicero's account of the theft and publication of the legal calendar portrays a worthy triumph over the pontiffs. It also makes Flavius the proverb's posterboy who has successfully outwitted those privileged with greater knowledge than himself; he has hoodwinked some theoretically sharp-sighted crows.

Cicero's anecdote is a celebration of publication, both for making information available and for revealing its value. The vanity of the pontiffs' desperate attempts to salvage some influence by inventing a new form of privileged access to the law is similarly revealed, in a mirroring of Flavius's publication of the calendar: "Quae dum erant occulta, necessario ab eis qui ea tenebant petebantur; postea vero pervolgata atque in manibus iactata et excussa, inanissima prudentiae reperta sunt, fraudis autem et stultitiae plenissima." ${ }^{31}$ Whereas Cicero presents the calendar published by Flavius as intrinsically useful, the formulae serve only to give artificial authority to those with access to them. In both instances, it is the publication of privileged information that has revealed its true worth. In Flavius's case, the phrase "eorum sapientiam compilarit" explicitly presents his valuable, revelatory publication as a form of intellectual theft.

The proverb's association with theft becomes even more apparent in the second of Erasmus's two examples from Cicero, taken from the speech defending the provincial governor Flaccus against accusations of corruption. Cicero here uses the proverb in a similar vein, although this time it is laced with irony. Cicero's defence of Flaccus again depends largely upon discrediting his opponents-in this instance, the prosecution witness Heraclides of Temnus, singled out in a larger attack on the unreliability of Greek witnesses: "Idem in actione pro L. Flacco: Hic Hercule 'cornici oculum' ut dicitur: nam hunc Hermippum, hominem eruditum, civem suum, cui debebat esse notissimus,

\footnotetext{
MA: Harvard University Press, 1977), 214-17. The Latin text of Pro Murena included in Macdonald's translation emends Erasmus's "ediscendos," referring to the public ability to learn the published dates, to "ediscendis," referring to Flavius's memorization of the individual days in order to publish them collectively. Cicero adopts a more characteristically favourable view of lawyers in De Oratore, 1.186, in which he emphasizes the utility and ease of studying the law, whose false reputation for difficulty derives from the protective secrecy of the pontiffs: Cicero, De Oratore Books I-II, trans. E. W. Sutton (Cambridge, MA: Harvard University Press, 1942; repr. 1948), 128-31.

31. "While these formulas were secret, you had to beg for them from those who knew them. Later, however, when they had been published, bandied about, and thoroughly sifted, they were seen to be not only devoid of all sense but positively brimming with stupidity." Cicero, Pro Murena, 11.26 (218-19).
} 
percussit." 32 Heraclides had been exposed for embezzling public funds in Temnus before he defrauded Hermippus, who should have been fully aware of his lack of financial probity: the proverb, previously employed to praise skilful deception, here expresses ironic disbelief at its success. Cicero's sympathy for Hermippus, "pudentissimum atque optimum virum, veterem amicum atque hospitem meum, splendidissimum atque ornatissimum civitatis suae," does not quite disguise his contempt for the naivety with which Hermippus has allowed himself to be fooled. ${ }^{33}$ Even the pupils whom Heraclides purports to teach have shown greater wisdom than Hermippus: "habebat enim rhetor iste adulescentes quosdam locupletis, quos dimidio redderet stultiores quam acceperat; neminem tamen adeo infatuare potuit ut ei nummum ullum crederet." ${ }^{34}$ In both examples, then, Cicero uses the proverb to refer to a theft carried out against the odds and against victims who should have known better. The chief difference is that whereas Flavius emerges from his theft with his honour intact, irony turns praise of the swindler Heraclides into criticism instead.

\section{Theft as foolish presumption: Erasmus's wise and ancient crows}

Just as Erasmus's publication of biblical commentaries concerned theologians (according to Folly), so his publication of the Adages worried those humanists who saw this contribution to the intellectual republic as a betrayal of the scholarly privilege that earned them public respect. ${ }^{35}$ As a fellow publisher of privileged information, Erasmus might be expected to sympathize with Flavius. However, his interpretation of the proverb quickly turns away from the Ciceronian sense of ironic poetic justice against more or less deserving crows towards criticism of those who lack reverence for the ancient authorities from whom they

32. "Again in the speech for the defence of Lucius Flaccus: 'Here, by Hercules, is a case of the proverbial crow's eye. For he swindled Hermippus here, a learned man, his own fellow-citizen, who should have been thoroughly acquainted with him."' Erasmus, Adage 275, ASD, 2.1:380-81; CWE, 31:296. Cf. Cicero, Pro Flacco, 46, trans. C. Macdonald (Cambridge, MA: Harvard University Press, 1977), 494-95. 33. "A most honourable and upright man and an old friend and host of mine, the most illustrious and distinguished man of his city." Cicero, Pro Flacco, 48 (496-97).

34. "For this teacher of rhetoric had some rich young men to make half as stupid again as they were when he took them on, but he could never make them stupid enough to lend him a single penny." Cicero, Pro Flacco, 47 (494-95).

35. Eden, Friends Hold All Things in Common, 143. 
acquire their wisdom. He explains the proverb's meaning as follows: "Perinde valere videtur cornicum oculos configere, quasi dicas novo quodam invento veterum eruditionem obscurare efficereque, ut superiores nihil scisse, nihil vidisse videantur. Effertur autem per ironiam."36 This explanation represents a considerable departure from the Ciceronian examples Erasmus quotes, in which property (legal information in Pro Murena and money in Pro Flacco) is stolen but not devalued, and in which irony is directed primarily at the foolish victims of theft. Yet the irony also applied to Heraclides introduces a new direction in Erasmus's discussion, allowing him to suggest that the proverb's irony may be directed not at the crows but at those modernizers who mistakenly believe they surpass the ancients, devaluing rather than stealing the knowledge that has been passed down over centuries in a theft not of intellectual property but of intellectual credit. Erasmus demonstrates this ironic application in his two fourth-century examples of the proverb's use, which associate it explicitly with the transfer and status of knowledge.

The first is from Jerome, who defends himself in In Rufinum precisely against the accusation that his modernizing translations of the Bible falsely challenge the authority of the Septuagint. ${ }^{37}$ In his defence, Jerome quotes the preface to his translation of the Book of Chronicles, in which he argues that while he respects scriptural authority, he also recognizes the corrupt state of the source texts:

In eadem sententia usus est divus Hieronymus Apologetico adversus Rufinum secundo: Nunc vero, cum pro varietate regionum diversa ferantur exemplaria et germana illa antiquaque translatio corrupta sit atque violata, nostri arbitrii putas, aut ex pluribus iudicare quid versum sit, aut novum opus in vetere condere illudentibusque Judaeis cornicum, ut dicitur, oculos configere. $^{38}$

36. “The meaning of 'to pierce crows' eyes' seems to be: to put the learning of older generations in the shade with some new discovery, and make it appear that earlier people knew nothing, have seen nothing. It is uttered in irony." Erasmus, Adage 275, ASD, 2.1:381; CWE, 31:296.

37. Jerome, In Rufinum, ed. and trans. Pierre Lardet (Paris: Cerf, 1983), 2.27 (178-79).

38. "Jerome, in his second apologetic against Rufinus, used it in the same way: 'Now, indeed, owing to the diversity of the regions, different copies are in circulation, and the genuine old translation has been corrupted and spoilt; and so you may think it within our province either to judge between several as to which is authentic, or to found a new work on the old one, and when the Jews laugh at us, as they 
Jerome's defence is that he is indeed a modernizer, but that he is a qualified and respectful one, whose translations restore the value of the original texts. Defence soon turns into attack, as Jerome then uses the proverb in its first Ciceronian sense, proclaiming that his translation represents a triumph over the Jews, stealing from them both their exclusive access to scriptural texts and their consequent entitlement to mock rivals to that authority.

Jerome's exultant use of the proverb hints at the uncomfortable relationship between the early Christian fathers and the Jews who held the sources of scripture. Pierre Lardet presents Christian dependence on and rivalry with the Jews in terms that recall Erasmus's proverb: "Le culte de l'hebraica veritas [...] vise, en recourant [aux juifs] [...], à les battre sur leur terrain." ${ }^{39}$ This rivalry is reflected in the antagonistic imagery commonly employed by Augustine and Jerome to equate the acquisition of knowledge with military plunder from an enemy, or the spoils of warfare; Kathy Eden has traced Erasmus's intellectual shift away from this aggressively possessive conception of intellectual property towards the friendly commonwealth evoked in the Adages. ${ }^{40}$ Accordingly, Erasmus's reading of Jerome delicately balances the modernizer's triumph with a continuing respect for the Jewish authority on which it nevertheless depends: "Haec Hieronymus sentiens, quasi sua castigatione prolata Judaei iam nihil scituri viderentur, a quibus id temporis Veteris Testamenti veritas petebatur." ${ }^{41}$ Erasmus's own Greek edition and Latin translation of the New Testament, published in the same year as his edition of the complete works of Jerome, could in turn be seen as a challenge to Jerome's Vulgate; his sensitivity to the authority of ancient sources perhaps reflects a fellow modernizer's awareness of the criticism of presumption to which he could be exposed. ${ }^{42}$

say, to pierce their crows-eyes." Erasmus, Adage 275, ASD, 2.1:381-82; CWE, 31:296. This translation replaces the earlier versum ("what was translated") with the later verum ("which is authentic"): see R. A. B. Mynors's note (CWE, 31:296).

39. Pierre Lardet, L’Apologie de Jérôme contre Rufin: un commentaire (Leiden: Brill, 1993), 102n176, dx.doi.org/10.1163/9789004312814.

40. Kathy Eden, “'Between Friends All Is Common': The Erasmian Adage and Tradition,” Journal of the History of Ideas 59 (1998): 405-19, 406, dx.doi.org/10.2307/3653894.

41. "Jerome means by this to suggest that his examination of texts might seem to impute ignorance to the Jews, to whom at that time one had to go to get the truth of the Old Testament." Erasmus, Adage 275, ASD, 2.1:382; CWE, 31:296.

42. Novum Instrumentum (Basel: Johann Froben, 1516); Omnium operum divi Hieronymi Stridonensis (Basel: Johann Froben, 1516). On this edition, see Jerome, Opera Pars III: Opera Polemica I: Contra 
The implicit insult in Jerome's use of the proverb is made explicit in Erasmus's final example, taken from the philosophers' feast in Macrobius's Saturnalia. ${ }^{43}$ The proverb is employed by Evangelus, an uninvited guest at the banquet, whose boorish interventions nevertheless provide useful challenges to the other conversationalists' philosophical discussion. ${ }^{44}$ Evangelus reacts to the respected Greek physician Dysarius's defence of a simple diet as if it were nonsense, and derisively invites another Greek, Eustathius, to respond with a similarly nonsensical counter-argument: "Ut suis telis lingua violenta succumbat et Graecus Graeco eripiat hunc plausum, tamquam cornix cornici oculos effodiat." ${ }^{45}$ Evangelus here conflates "cornicum oculos configere" with a related proverb, "corvus oculum corvi non eruit" (one crow does not put out the eyes of another), and bowdlerizes them both. ${ }^{46}$ While the first indeed suggests similarity, as like is used to conquer like, the second specifies a necessary difference: the like methods triumphantly adopted by the victor must be alien, since crows themselves do not attack their own kind. Evangelus's wilful or ignorant omission of the negation thus allows him to savour the prospect of witnessing a scene of mutual self-destruction. Yet while his rude intervention scathingly dismisses Greek speech and intelligence, its philosophical validity is confirmed by Symmachus, who politely rephrases his insulting request. ${ }^{47}$ By respectfully reframing the task befalling Eustathius as intellectually possible, philosophically desirable, and more appropriate coming from a fellow Greek, Symmachus rescues him from the malice behind Evangelus's challenge and restores the pleasure and value of intellectual debate. Like Erasmus, Symmachus

Rufinum, ed. P. Lardet (Turnhout: Brepols, 1982), 219-34.

43. Macrobius, Saturnalia, ed. and trans. Robert A. Kaster, 3 vols. (Cambridge, MA: Harvard University Press, 2011), 6.5.2 (3:186-87).

44. On the roles and characters of the speakers in this "colloquium liberale," see Kaster, in Macrobius, 1:xxvii-Xxxv.

45. "In this way the language of violence will be the victim of its own weapons and just like one crow pecking at another's eyes, one Greek will steal the applause from another." Erasmus, Adage 275, ASD, 2.1:382; CWE, 31:296.

46. On "corvus oculum corvi non eruit," see Otto, 93. On the Renaissance English equivalent, "one crow never puts out another's eyes," see Morris Palmer Tilley, A Dictionary of the Proverbs in England in the Sixteenth and Seventeenth Centuries: A Collection of the Proverbs Found in English Literature and the Dictionaries of the Period (Ann Arbor: University of Michigan Press, 1950; repr. 1966), 131 (C856). 47. Macrobius, 6.5 .3 (3:186-89). 
thus removes aggressive competition from the exchange of knowledge to which the proverb refers.

Macrobius's mockery of the mocker Evangelus, unable to appreciate the subtlety and wisdom of Greek crows, is itself a demonstration of the proverb in action. It also prompts a further change of direction in Erasmus's discussion, warning against the triumphalism displayed (with different degrees of entitlement) by both Evangelus and Jerome:

Illud non ab re fuerit admonere lectorem, ut etiam atque etiam consideret, num cornicum vivacitas et concordia huic adagioni locum fecerit. Siquidem cornix antiquitus concordiae symbolum erat. Eiusdem vivacitas etiam Graeco proverbio celebrata est. Ut is videatur cornicum oculos velle configere, quisquis ea quae antiquitas magno consensu approbavit, damnare ac rescindere convellereque conetur. ${ }^{48}$

Antiquity's celebration of longevity and harmony is itself used to argue against the presumption of calling its wisdom into question. Erasmus's warning against such presumption continues even in his concluding acknowledgement of the skilful precision that the proverb's imagery, taken literally, displays: "Nec admodum absurdum, si quis in hunc modum accipiat, ut dicatur oculos cornicum configere, qui perspicacissimis occulatissimisque visum adimat offundatque tenebras aut qui rem ipsissimam acu, quod aiunt, tangat, tantus videlicet artifex, ut non solum scopum aut avem, verum et ipsos oculos iaculo feriat." $^{49}$

48. "It would not be inappropriate to suggest to the reader that he should consider very carefully whether crows have given rise to this proverb through their long life and peaceful cohabitation. Indeed the crow was the symbol of concord in Antiquity; and its length of life is celebrated in a Greek proverb. So that anyone who tried to bring into contempt, cancel or remove the things which antiquity approved with one accord, may be said to wish 'to pierce the crows' eyes." Erasmus, Adage 275, ASD, 2.1:382; CWE, 31:296-297. The concord of crows is described by Aelian, On the Characteristics of Animals, 3.9, trans. A. F. Scholfield, 3 vols. (Cambridge, MA: Harvard University Press, 1958), 1:164-67. Alciato, whose emblems often allude to Erasmus's Adages, similarly uses crows to symbolize concord in Andrea Alciato, Emblematum Libellus (Paris: Chrestien Wechel, 1534), 10.

49. "This is not so absurd, if one takes 'piercing the eyes' to mean removing the sight from those who have it at the clearest and best, so letting the darkness flood in; or to mean touching the very thing with the point, as they say, so skilfully that not only the target or the bird is pierced by the dart, but its very eyes." Erasmus, Adage 275, ASD, 2.1:382; CWE, 31:297. 
Even such a skill is to be used with caution: where Jerome has successfully employed it to increase light by disseminating improved access to the scriptures, Evangelus has attempted to use it to promote blind ignorance instead. For all the violence of these metaphors for the exchange of knowledge, Erasmus shows that piercing crows' eyes is a delicate operation, and only to be entrusted to those qualified to carry it out. Erasmus's commentary thus begins by praising Flavius for his theft and publication of privileged information but ends by warning against the intellectual presumption that such a transfer of knowledge may represent.

\section{Ancient ambivalence to Flavius: upstarts versus crows}

Erasmus's difficulty with the proverb reflects the same concern for quality control that he expresses in his commentary on "festina lente." This anxiety about intellectual presumption is in stark contrast with the anxiety about social presumption that feeds Flavius's ancient critics, Livy and Valerius Maximus, who object to his actions and to his political promotion largely out of respect for social hierarchies and proper reverence for the gods. While Cicero enjoys Flavius's triumph over the pontiffs, Livy and Valerius focus sympathetically on the noble resentment he inspires, as much for reasons of class and privilege as for his theft-which they pass over to concentrate on the greater social threat posed by publication.

Livy's first reference to Flavius emphasizes his humble status: "Eodem anno Cn. Flavius Cn. filius scriba, patre libertino humili fortuna ortus, ceterum callidus vir et facundus, aedilis curulis fuit." ${ }^{20}$ Livy's concession towards Flavius's intellect, in spite of his lowly birth, hints quietly at disapproval through the ambiguous adjective "callidus," which may praise cleverness or denote an element of low cunning-precisely the double-edged quality at the heart of "cornicum oculos configure." ${ }^{1}$ Similarly, Livy reiterates this emphasis on Flavius's lowly birth immediately before describing his publication of the ius civile, as if his status were the most significant aspect of the anecdote: "Ceterum,

50. "In the same year a government clerk, Gnaeus Flavius, the son of Gnaeus, was curule aedile. Born in humble circumstances-his father being a freedman-he was, for the rest, a man of shrewdness and eloquence." Livy, Ab Urbe Condita, 9.46.1, trans. B. O. Foster, 13 vols. (Cambridge, MA: Harvard University Press, 1957), 4:348-49.

51. Otto, 93. On "callidus" as derogatory in Livy, see Oakley, 3:616. 
id quod haud discrepat, contumacia adversus contemnentes humilitatem suam nobiles certavit; civile ius, repositum in penetralibus pontificum, evolgavit fastosque circa forum in albo proposuit, ut quando lege agi posset sciretur." ${ }^{52}$ Livy makes no explicit reference to theft here; it is Flavius's publication that is called into question.

Livy's ambivalence towards Flavius is coloured partly by his own snobbery and partly by Flavius's link to the Roman censor Appius Claudius Caecus, commonly tainted by association with the reactionary elitism of the rest of his family, but subject also to criticism for his radical disregard for social hierarchy: "Ceterum Flavium dixerat aedilem forensis factio, Ap. Claudi censura vires nacta, qui senatum primus libertinorum filiis lectis inquinaverat." ${ }^{53}$ The pejorative verb "inquinaverat" reflects Livy's objection to social and political advancement; his consequent disapproval of Appius is later confirmed through the same back-handed adjective "callidus" that he had used of Flavius. ${ }^{54}$

Following Livy, Valerius also focuses less on Flavius's achievements than on the anger his promotion aroused among the nobility: "Ius civile per multa saecula inter sacra caerimoniasque deorum immortalium abditum solisque pontificibus notum $\mathrm{Cn}$. Flavius, libertino patre genitus et scriba, cum ingenti nobilitatis indignatione factus aedilis curulis, vulgavit ac fastos paene toto foro exposuit." ${ }^{55}$ Valerius and Livy, whose narratives constitute the most critical ancient accounts of Flavius, are unique in representing his actions as a vulgarization rather than as a theft: Valerius's "vulgavit" in this passage echoes

52. "At all events, there is no difference of opinion about the stubbornness of his contention with the nobles, who despised his lowly birth. He published the formulae of the civil law, which had been filed away in the secret archives of the pontiffs, and posted up the calendar on white notice-boards about the Forum, that men might know when they could bring an action." Livy, 9.46.4-5 (4:350-51).

53. "Now Flavius had been elected aedile by the faction of the market-place, which had become powerful in consequence of the censorship of Appius Claudius. Claudius had been the first to debase the senate by the appointment of the sons of freedmen." Livy, 9.46.10 (4:350-53). On Appius and the negative tradition surrounding the Claudii, see Oakley, 3:350-72; on Livy's own snobbery, see Oakley, 3:606.

54. Livy, 10.22.7 (4:442-43); see also Oakley, 4:244.

55. "For many centuries the civil law was hidden among the rituals and ceremonies of the immortal gods and known only to the Pontiffs. Then Cn. Flavius, son of a freedman and a scribe, was elected Curule Aedile to the vast indignation of the nobility and made it public, displaying the calendar all over the Forum so to speak." Valerius Maximus, Memorable Doings and Sayings, 2.5.2, ed. and trans. D. R. Shackleton Bailey, 2 vols. (Cambridge, MA: Harvard University Press, 2000), 1:160-61; on Valerius's considerable popularity in the Renaissance, see 1:4. 
the "evolgavit" in Livy $(9.46 .5,350)$; his disapproval of such indiscriminate publication and profanation is emphasized by "paene toto foro." Valerius goes on to present the nobles' indignation as fully justified, even if he condemns it for its lack of restraint. ${ }^{56}$

Valerius's respect for social hierarchies is reflected in his reverence for the procedure due to the gods, which must similarly be protected from profanation through exposure to the public. This is seen in his exemplary anecdote about Attilius, sentenced to death by Tarquin for allowing a book of secret civic rituals to be copied - a criminal act of publication almost identical to Flavius's, but for its additional dishonouring of the gods. ${ }^{57}$ In a similar example, Valerius attributes Appius's cognomen "Caecus" to divine punishment for his contemptuous disregard for the gods: at his prompting ("auctore Appio censore"), the patrician Potitii transferred to public slaves the celebration of the rites of Hercules, entrusted directly to their family by the god; the Potitius family virtually died out within the year, while Appius, albeit several years later, was struck blind ("Appius vero luminibus captus est"). ${ }^{58}$ Appius's attack on a patrician monopoly over religion closely resembles Flavius's attack on the pontiffs' monopoly over Roman law-but leads to punishment, not reward.

While Livy and Valerius thus hint at the shared political ideology of Flavius and Appius, only two of the ancient sources for Flavius's theft explicitly link them: Pomponius's account, included in the Digest, and Pliny's. Pomponius's specification that Flavius was employed by Appius, "scriba eius," radically changes the nature of Flavius's theft, implicitly pitting the clerk against his master; in the absence of reference to the pontiffs, Appius becomes the sole victim of the theft, and Pomponius suggests that it is by the will of the people (rather than by Appius, as Livy implies) that Flavius is promoted. Yet while Pomponius's account, like Cicero's, celebrates Flavius, it includes neither Cicero's proverb nor its irony: nothing in it suggests that Appius deserves to be mocked as a proverbial crow, not least as the image of piercing crows' eyes is, in this instance, deeply inappropriate. There is nothing clever about stealing from

56. Valerius, $9.3 .3(2: 322-25)$.

57. Valerius, $1.1 .13(1: 26-27)$.

58. Valerius, 1.1 .17 (1:28-31). Livy also acknowledges this tradition: Livy, 9.29.10-11 (4:276-77); see Valerius Maximus, Memorable Deeds and Sayings: Book I, trans. D. Wardle (Oxford: Clarendon Press, 1998), 120. 
a blind man, and especially not via a proverb that focuses specifically on vision, or on pulling the wool over already sightless eyes. ${ }^{59}$

The oddity of the apparent turning of Flavius against Appius-and of a scribe being rewarded for deceiving his master-had in fact already been resolved by Pliny, who suggests not only that Appius condoned Flavius's theft, but even that he was complicit in it: "Hic [Cn. Flavius Anni filius] namque publicatis diebus fastis, quos populus a paucis principum cotidie petebat, tantam gratiam plebei adeptus est-libertino patre alioqui genitus et ipse scriba Appi Caeci, cuius hortatu exceperat eos dies consultando adsidue sagaci ingenio promulgaratque-, ut aedilis curulis crearetur." ${ }^{30}$ Flavius's natural shrewdness would certainly have benefited greatly from Appius's practical help; equally, it is plausible that Appius-who had attacked the patrician monopoly through his treatment of the Potitii and his promotion of Flavius, but who could not have published the calendar or the ius civile without betraying his class-might deliberately have turned one of his blind eyes to Flavius's theft.

If Appius indeed exploited his literal blindness to claim metaphorical blindness to a theft in which he was complicit, then blindness has been used to blind, and "cornicum oculos configere" has been turned on its head. For politically, blind Appius is remarkably clear-sighted; even Valerius praises him for his successful government of Rome, and most notably for saving her from a discreditable peace treaty with Pyrrhus: "Hunc caecum aliquis nominet, a quo patria quod honestum erat per se parum cernens coacta est pervidere? ${ }^{61}$ Valerius's praise of both Flavius and Appius is nevertheless qualified, like

59. On blind resentment of theft-both for the unfair advantage that sighted thieves have over their blind victims, and particularly for the unfair disadvantage that their visibility presents to thieves who are blind-see Denis Diderot, Lettre sur les aveugles, ed. Marion Hobson and Simon Harvey (Paris: Flammarion, 2000), 37-38; see also Kate E. Tunstall, Blindness and Enlightenment (New York and London: Continuum, 2011), 75.

60. "It was he [Gnaeus Flavius son of Annius] who first published the dates for legal proceedings, which it had been customary for the general public to ascertain by daily enquiry from a few of the leading citizens; and this won him such great popularity with the common people-he was also the son of a liberated slave and himself a clerk to Appius Caecus, at whose request he had by dint of natural shrewdness through continual observation picked out those days and published them-that he was appointed a curule ædile." Pliny, Natural History, 33.6.17, trans. H. Rackham, 10 vols. (Cambridge, MA: Harvard University Press, 1968), 9:14-17.

61. "Call him blind if you will, by whom his country, which ill perceived what was honourable by herself, was forced to see it plain.” Valerius, Memorable Doings, 8.13 .5 (2:264-65). 
Livy's, by a context of snobbery and respect for divine mystery that is more condemnatory of publication than of theft. This sociological anxiety about publication is distinct from Erasmus's epistemological concerns, yet it resembles Erasmus's respect for the ancient Egyptians' reverent mystery and deployment of hieroglyphics. Epistemological and sociological anxiety about the indiscriminate revelation of sacred wisdom, presented by unqualified editors to an unfiltered audience, finds clear echoes in Renaissance France.

\section{Renaissance representations of Flavius's publication and theft}

The earliest of these Renaissance echoes is heard in Flavius's original domain, in which his actions are chiefly celebrated: the law. Guillaume Budé's Annotationes on Justinian's Digest refers readers to Livy's account of Flavius's theft and then quotes in full the versions by Cicero and Valerius. This leads Budé, like Erasmus, to comment on the meaning of Cicero's proverb, which he explains through reference to another proverb also found in the Adages: "Cornicum oculos configere (ut id obiter dicamus). Cicero in exemplo superiori pro eo posuit quod est callidos et versutos homines versutia et calliditate supplantare et eluctari. Ut enim clavus clavo truditur: sic vafritia vafer: et ars eluditur arte."62 Where Erasmus's discussion of "Clavum clavo pellere" uses predominantly negative examples of countering like with like, Budé wraps the pejorative nouns versutia and vafer within the more ambiguous calliditas and ars, both of which may have either positive or negative connotations. ${ }^{63}$ Perhaps Budé, under the influence of the Digest's and Cicero's lawyerly enthusiasm for Flavius, thus

62. “'To pierce the crows' eyes' (in this context, en passant). Cicero in the above example shows that it means to overthrow and surmount cunning and clever men through cleverness and cunning. Just as a nail is driven out by a nail, so craftiness is foiled by craftiness and artfulness by artfulness" (my translation). Annotationes Guillielmi Budei Parisiensis, Secretarii Regii in quattuor et viginti Pandectarum libros ([Paris]: Jodocus Badius Ascensius, 1508), fol. ciir ${ }^{\mathrm{r}}$. On Erasmus's admiration for Budé's Annotationes, see Marie-Madeleine de La Garanderie, Guillaume Budé, philosophe de la culture, ed. Luigi-Alberto Sanchi (Paris: Garnier, 2010), 317-18.

63. "Clavum clavo pellere" appears in Erasmus, Adage 104, ASD, 2.1:218; CWE, 31:148-49. As if in ironic demonstration of like replacing like, it initiates a series of reflections on the dangers of making a bad situation worse: see Adages 106-12, ASD, 2.1:220-24; CWE, 31:150-53. Adage 111 is equivalent to bringing coals to Newcastle, and Adage 112 to preaching to the converted, or to teaching one's grandmother to suck eggs. 
hopes to distinguish between the pontiffs' skill in maliciously preserving their secrets and Flavius's almost identical skill in beneficially uncovering them.

Again like Erasmus, Budé then quotes Cicero's Pro Flacco and Jerome's preface to his translation of the Book of Chronicles as further examples of the proverb's use. Yet unlike Erasmus, he continues to interpret the proverb positively, expressing his desire that a modern Tribonianus (the jurist chiefly responsible for compiling Justinian's Digest) might in turn "pierce the crows' eyes" of modern jurists by providing a single, clear, and authoritative presentation of the law. ${ }^{64}$ Such a Tribonianus or Flavius might usefully displace the multiple commentaries whose self-perpetuating accumulation of references and interpretations occludes rather than clarifies understanding of the law. These uncontrolled legal commentators resemble the unregulated, shoddy printers of Erasmus's "festina lente," and the damage they do to scholarship is the same; it leads to the high ironic praise extended by Erasmus's Folly to lawyers: "Inter eruditos iureconsulti sibi vel primum vindicant locum neque quisquam alius aeque sibi placet, dum Sisyphi saxum assidue volvunt ac sexcentas leges eodem spiritu contexunt, nihil refert quam ad rem pertinentes, dumque glossematis glossemata, opiniones opinionibus cumulantes, efficiunt ut studium illud omnium difficillimum esse videatur." ${ }^{65}$ Faced with these modern versions of the pontiffs, whom Cicero had berated in De Officio for falsely imputing difficulty to the learning of law, Budé seeks another Flavius. He concludes his tirade against redundant commentators by specifying that he refers only to the "insolentibus" and "ineptis," as distinct from those whose true scholarship deplores ostentatious display and publishes only what is useful and serious. ${ }^{66}$

As a commentator on a legal text who denounces legal commentaries, Budé is in a similar position to Erasmus, criticizing presumptuous modernizers

64. Budé, fol. ciiv. This is a rare endorsement of Tribonianus: on humanist ambivalence towards his admirable compilation but indistinguishable conflation of multiple laws, see Valérie Hayaert, "Mens emblematica" et humanisme juridique: le cas du "Pegma cum narrationibus philosophicis" de Pierre Coustau (1555) (Geneva: Droz, 2008), 111-47.

65. "Amongst the learned the lawyers claim first place, the most self-satisfied class of people, as they roll their rock of Sisyphus and string together six hundred laws in the same breath, no matter whether relevant or not, piling up opinion on opinion and gloss on gloss to make their profession seem the most difficult of all." Erasmus, Moriae Encomium, in ASD, 4.3:142; Praise of Folly, in CWE, 27:125.

66. The "immoderate" or "arrogant" and the "silly," "pedantic," or "inept." Budé, fol. ciiv. 
of ancient sources. Like Erasmus, however, Budé is rescued from the risk of hypocrisy by the quality of his erudition-as testified by his fellow jurist Pierre Coustau in his own Adversariorum on Justinian's Digest. In a lengthy preface, Coustau singles out two commentators on the Digest, Budé and François de Connan, as shining examples of modern legal scholarship, "viri [...] doctissimi et eloquentissimi." ${ }^{7}$ Budé thus exemplifies the proverb in action in its most positive sense, driving out poor nails with the quality of his good nail instead. In contrast, Coustau condemns those who desire to be praised for their exclusive learning and so set themselves up (falsely) as new pontiffs, from whom answers to the most serious legal questions must be sought, in an echo of Cicero, "tanquam a Caldaeis." 68 The analogy and the expression show that Coustau has a second Flavius in mind, one who, like Budé, might use his erudition to steal the arcane secrets of the law from accumulated obfuscation and publish them simply and clearly for all.

\section{Distinguishing between thieves: Flavius, Prometheus, and the Satyr}

Budé's concern to distinguish himself as a legitimate legal commentator combines with Erasmus's anxiety about the intellectual presumption of modernizers to influence other Renaissance jurists' reactions to Flavius. This can be seen in two examples from the emblematic tradition, which, like the emerging genre of the essay, was greatly influenced by both the form and content of Erasmus's Adages. ${ }^{69}$ Both examples echo Erasmus's cautious application of "cornicum oculos configere" as a warning against intellectual presumption, while at the same time demonstrating a jurist's familiarity with the Digest's celebration of Flavius. The first comes from the university professor (and, later, jurist) Claude Mignault, who in 1571 contributed significantly to Nicolas Chesneau's revised and expanded edition of Erasmus's Adages; in the same year, Mignault uses Erasmus's proverb in his highly influential commentary on the Emblemata,

67. "Most learned and most eloquent men." Pierre Coustau, Adversariorum ex Pandectis Iustiniani imperatoris (Lyons: Macé Bonhomme, 1554), fol. [ $\left.\gamma^{3}\right]^{\mathrm{v}}$.

68. Coustau, Adversariorum, fol. $\beta^{\mathrm{r}-\mathrm{v}}$.

69. See Irene Bergal, "Pierre Coustau's Pegme: From Emblem to Essay," in Lapidary Inscriptions: Renaissance Essays for Donald A. Stone, Jr., ed. Barbara C. Bowen and Jerry C. Nash (Lexington, KY: French Forum, 1991), 113-22. 
first published in 1531, of his fellow jurist Andrea Alciato. ${ }^{70}$ The second example comes from the jurist Pierre Coustau, who illustrates Erasmus's proverb in his Pegma, a collection of Latin emblems first published in 1555; a partial French translation by Lanteaume de Romieu was published simultaneously in 1555 , followed by a complete translation in $1560 .{ }^{71}$ Mignault and Coustau both recognize the epistemological value of Flavius's theft, but nevertheless use "cornicum oculos configere" to focus on the danger of knowledge falling into the wrong hands: Mignault implicitly cautions his readers about their role as responsible interpreters of his work, while Coustau, reflecting Erasmus's distinction between the qualifications of Jerome and of Evangelus, replaces Flavius with another celebrated thief, Prometheus, whom he contrasts with his less successful emulator, the Satyr.

In his commentary on Alciato's fourth emblem, "In deo laetandum" ("We should rejoice in God"), Mignault embarks on a Platonic discussion of poetic enigmas. Just as Erasmus cites the ancient Egyptians' use of hieroglyphics as a wise precaution against the profanation of divine mystery, so Mignault defends poets who use allegory or myth to preserve an element of respectful mystery in their revelation particularly of theological wisdom:

Eos [poetas veteres] enim tale quippiam in fabulosis narrationibus observare voluisse crediderim, quale priores illi iurisperiti (ut Marcus Tullius in libris De oratore memorat) observarunt, qui ut auctoritatem

70. Adagiorum Des. Erasmi Roterdami Chiliades quatuor cum sesqui centuria (Paris: Nicolas Chesneau, 1571); Claude Mignault, Omnia Andreae Alciati V. C. Emblemata (Paris: Denis du Pré, 1571). On Mignault's editorial role in the 1571 Adages, shown by his address to the reader although not indicated on the title page, see Vuilleumier Laurens, 16-20; on his commentary on Alciato, see Philip Ford, "Le Commentaire de Claude Mignault sur les Emblèmes d'Alciat," Les Cahiers de l'Humanisme 3-4 (2002-03): 183-98; on his teaching, see Anthony Grafton, "Teacher, Text and Pupil in the Renaissance Class-Room: A Case Study from a Parisian College," History of Universities 1 (1981): 37-70.

71. Pierre Coustau, Pegma, cum narrationibus philosophicis (Lyons: Macé Bonhomme, 1555), text and (unattributed) translation available online at French Emblems at Glasgow, accessed 28 May 2020, emblems.arts.gla.ac.uk/french/emblem.php?id=FCPb043; Le Pegme, trans. Lanteaume de Romieu (Lyons: Barthélemy Molin, 1560), online at French Emblems at Glasgow, accessed 28 May 2020, emblems.arts.gla.ac.uk/french/emblem.php?id=FCPa043. Many of Coustau's emblems relate to legal issues: see Alison Saunders, "Introduction," accessed 28 May 2020, emblems.arts.gla.ac.uk/french/ books.php?id=FCPa\&o; see also Bergal, 114. On Coustau's Pegma and the relationship between jurists and the emblematic tradition, see Hayaert, "Mens emblematica" et humanisme juridique. 
assequerentur et augerent, artem suam vulgarem esse noluere, nisi cum Gnaeus Flauius primus eam propalavit, qui eam ob rem dictus est cornicum oculos confixisse. [...] Eodem plane modo veteres illi poetae sub aliquo cortice obscuro, fabulosisque ornamentis res suas occultarunt, ut imperitam plebeculam a mysteriis illis sapientiae reconditoris arcerent. ${ }^{72}$

The context of Mignault's analogy suggests a respect for the secrecy of the pontiffs, as of the poets, that is in marked contrast to his source, Cicero. Mignault's attitude to publication and to Flavius-rather disguised by his simple reliance on the proverb-is consequently ambiguous: like Erasmus, Mignault would preserve a qualified openness in matters of poetry and of religion, whose mysteries may legitimately be penetrated by those properly equipped to do so, but should not be debased through revelation to the ignorant. ${ }^{73}$ Mignault thereby echoes both Erasmus's concern that publication is a form of debasement and his desire (shared with Jerome) to be recognized as a qualified interpreter of religious (or, in Mignault's case, poetic) texts. For Mignault's respect for poetic secrecy implicitly questions his own role as a poetic commentator. His perceptive readings of Alciato make him, like Flavius, something of an intellectual thief, who skilfully discerns and indiscriminately publishes hidden truths. Mignault's defence for publishing his commentary thereby depends on the intelligence of his readers; if they are not qualified to read his book, then it has fallen into the wrong hands.

72. "For I would think that they [the ancient poets] tried to respect in their mythical stories something such as was maintained by those early lawyers (as Cicero relates in the De oratore), who, in order to acquire authority and to increase it, refused to allow their art to be common knowledge, until Gnaeus Flavius divulged it-for which deed he was said to be sharper than the sharpest [literally, "to have pierced the crows' eyes"]. [...] In just the same way those ancient poets hid their meanings under some dark shell and mythical ornaments, in order to keep ignorant common folk away from these mysteries of more recondite wisdom." Claude Mignault, "Commentary on the emblem 'In deo laetandum," in Theoretical Writings on the Emblem: a Critical Edition, ed. and trans. Denis Drysdall, accessed 28 May 2020, emblems.arts.gla.ac.uk/Mignault_Emblem4.html. As Drysdall points out, the reference is to Cicero's De Oratore, 1.41.186; "but Mignault is almost certainly thinking of Pro Murena, 11.25, since it is there that Cicero applies the saying Cornicum oculos configere to Gnaeus Flavius."

73. Mignault's ambivalence towards Flavius's publication is reflected in his interpretation of Alciato's emblem on Ulysses blinding Polyphemus as an example of cunning overcoming prudent wisdom; it echoes Erasmus's respect for the wisdom of ancient crows. See Mignault, Omnia Andreae Alciati V. C. Embemata. Cum commentariis (Antwerp: Christophe Plantin, 1581), 592; see also Ford, 190. 
Similarly, Coustau distinguishes between those who are and those who are not equipped to pierce crows' eyes in his emblem "In Satyrum," in which the titular Satyr, seeing Prometheus bringing down to earth the fire he has stolen from an insufficiently vigilant Jupiter, desires to embrace the flames, only to get his fingers burned. ${ }^{74}$ The fable derives from Plutarch; Erasmus similarly refers to it to emphasize that virtue lies not in an object (such as fire) but in the use to which it is put. ${ }^{75}$ Coustau's moralizing emblem uses the proverb to explain to the Satyr what distinguishes him from Prometheus, and so disqualifies him even from touching the divine flame that Prometheus safely carries to earth:

Qui potis es sacrae tabulas tractare Sophiae,

Et vel cornicum lumina confodere,

Cum te habeant fessum sulcus, vilesque quadrigae? ${ }^{76}$

The social distinction drawn between Prometheus and the lowly Satyr reflects practical considerations rather than the snobbery of Livy and Valerius. It is an analogy for the intellectual distinction between those who are and those who are not entitled, by the time they have spent studying it, to engage with theology; the emblem is directed against intellectual parvenus, or "contra sedentarios et cerdones, qui paulum ultra primas literas promoti, suo sensu in literis sacris versari volunt." 77 In the "narratio philosophica" or "narration philosophique"

74. Coustau, Pegma, [141]-45; Le Pegme, 183-87.

75. Plutarch, "How to profit by one's enemies," 2.86F, in Moralia, ed. and trans. Jeffrey Henderson, 15 vols. (Cambridge, MA: Harvard University Press, 1928), 2:6-9; Erasmus, Apophthegmatum opus (Paris: Simon de Colines, 1532), fol. $336^{\mathrm{v}}$. See Raymond Trousson, Le Thème de Prométhée dans la littérature européenne, 2 vols. (Geneva: Droz, 1976), 1:105.

76. "How can you handle the pages of sacred Wisdom, / And 'catch out the eyes of crows', no less, / When you're exhausted by a day's ploughing with your wretched team of oxen?" (translation unattributed), Coustau, Pegma, 142. The French edition alters these lines rather than translate the proverb: Coustau, $L e$ Pegme, 183. On Romieu's translation strategies, see Alison Saunders, “'Quis, quid, ubi, quibus auxiliis, cur, quomodo, quando?' or: The Curious Case of Pierre Coustau's Pegma," in An Interregnum of the Sign: The Emblematic Age in France; Essays in Honour of Daniel S. Russell, ed. David Graham (Glasgow: Glasgow Emblem Studies, 2001), 29-48, 46.

77. "Against the clerks and the cobblers, who having acquired a little learning, want to busy themselves with holy Scripture according to their own notions"; the translator (unattributed) also suggests "armchair experts" for sedentarios, and "craftsmen" for cerdones, in "In Satyrum," emblems.arts.gla.ac.uk/french/ emblem.php?id=FCPb043. 
that follows the emblem, Coustau emphasizes the "juste reprehension" that has fallen on "plusieurs nations" because of their ill-founded determination to "renouveller la religion," leading to a state of such theological instability that no two men have the same opinion, and that religious divergence becomes a point of pride. ${ }^{78}$ "Quot homines, tot sententiae" ${ }^{79}$ such diversity is, for Coustau, a punishment for heresy in itself. For both Mignault and Coustau, the intellectual curiosity suggested by the proverb should be confined to those qualified to undertake it without risk of getting burned. ${ }^{80}$

\section{Legitimizing theft: Flavius and Prometheus}

The risk of getting burned applies not only to unguarded thieves but also to imprudent publishers-as Protestants in sixteenth-century France were all too aware. The idea of literary theft consequently acquires a new value, acting (sometimes conspicuously) to disguise responsibility for a publication. The jurist Pierre de La Place spells out the dangers of publication in his Commentaires, which constitutes one of the earliest and most influential Protestant histories of the years leading up to the outbreak of the religious wars. ${ }^{81}$ The Commentaires

78. On the influence of Erasmus over Coustau's highly original inclusion of a narratio philosophica at the end of each emblem, see Bergal, 114-15. On "Sur le Satyre" and its validation both of expert and of majority opinion, see Hayaert, 79 and 102-09.

79. “There are as many opinions as people." Terence, Phormio, ed. and trans. John Barsby (Cambridge, MA: Harvard University Press, 2001), 60-61.

80. On curiosity's transformation in the Renaissance from a vice to a morally neutral or even positive quality, see Neil Kenny, Curiosity in Early Modern Europe: Word Histories (Wiesbaden: Harrassowitz Verlag, 1998), esp. 44-45 and 53-55. In contrast to Coustau, Alciato uses the punishment of Prometheus to illustrate the emblem "Quae supra nos, nihil ad nos" (What is above us does not concern us [my translation]): Alciato, Emblematum Libellus, 32. Similarly, Aneau refers to Prometheus's punishment in his emblem “Curiositas fugienda." Barthélemy Aneau, Picta poesis (Lyons: Macé Bonhomme, 1552), 90; available online at French Emblems at Glasgow, accessed 28 May 2020, emblems.arts.gla.ac.uk/french/ emblem.php?id=FANa078; translated as "Curiosité est à fuyr" in Barthélemy Aneau, Imagination poétique (Lyons: Macé Bonhomme, 1552), 119, and available online at emblems.arts.gla.ac.uk/french/ emblem.php?id=FANb077 (accessed 28 May 2020). See Trousson, 1:97.

81. [Pierre de La Place], Commentaires de l'Estat de la Religion \& Republique soubs les Rois Henry \& Francois seconds, \& Charles neufieme ([n.p.]: [n. pub.], 1565), fol. 19v (hereafter cited in the text). La Place was killed during the St. Bartholomew's Day massacres in Paris; his Commentaires covers the years 1556 to 1561 . 
was published anonymously, as a result of what is explicitly presented as a theft by an anonymous editor from an equally anonymous author reluctant to publish his work. ${ }^{82}$ In his prefatory address to the reader, the editor pointedly attributes the author's reluctance to publish to the repressive policies of the times:

Tout ainsi que c'est chose bien certaine qu'il n'est rien advenu de long temps en ce Royaume plus memorable et digne, dont la memoire soit conservee à la posterité, que ce qui est advenu de nos jours, et depuis mesmes le commencement du Roy Henry dernier: Aussi n'est-il moins certain et veritable, que d'en publier maintenant la verité par escript, ce n'est chose qui du tout soit hors de peril et danger. L'Autheur de ce livre pour ceste cause a facilement esté induict de mettre la main à cest œuvre, mais de pouvoir estre persuadé de le mettre en lumiere, ç’a esté chose impossible: estant fiché sur ce poinct qu'il n'est bon de dire la verité en tout temps ("Au Lecteur" [unpaginated]).

Criticism of the dangers of publication vaunts the bravery of the editor, who performs a valuable public service in stealing and publishing the Commentaires.

The "Au Lecteur" is preceded by a sonnet in which the anonymous editor first evokes the author's reluctance to publish and then justifies his own theft and unauthorized publication of the Commentaires through triumphant analogy with Flavius:

Mais le temps l'arresta et l'enferma si bien,

Que du tout nous fussions privez de ce grand bien,

N'eust esté mon larcin qui me sera louable:

Car ainsi l'Escrivain de l'Aveugle Romain

En l'escrin de son maistre osant mettre la main,

Fut bien recompensé d'un larcin profitable ([title page $\left.]^{\vee}\right)$.

82. The attribution of the Commentaires to La Place has been attested from an early stage: Pierre de Farnace's biography, in La Place, Traicté de l'excellence de l'homme chrestien et maniere de le cognoistre ([n.p.]: [n. pub.], 1575), fols [*5] $\left.\left.{ }^{\mathrm{r}}-{ }^{* *}\right]^{*}\right]^{\mathrm{v}}$, confirms he was working on just such a history in 1561 and 1562 (fols $\left[{ }^{*} 7\right]^{\mathrm{v}}-\left[{ }^{*} 8\right]^{\mathrm{r}}$ ); the Bibliothèque Nationale catalogue entry for the Commentaires (shelf-mark Res 8-Z DON-594) provides a later authority for the attribution: "Par P. de La Place, d'après une note ms. de Laurent Bouchel datée de 1584." 
The antonomasia ("l'Escrivain de l'Aveugle Romain"), suggesting that Flavius, like Appius, is sufficiently well known to need no further identification, is unsurprising in a jurist necessarily familiar with Justinian's Digest and thereby with Pomponius's emphasis on Flavius's employment by Appius ("scriba eius"), on his editorial fidelity ("nam nec Gnaeus Flavius de suo quicquam adiecit libro"), and on his reward ("adeo gratum fuit id munus populo, ut tribunus plebis fieret et senator et aedilis curulis"). Through analogy with Flavius, and in one of his most unambiguously positive representations in the French Renaissance, La Place's anonymous editor thus asserts his own reliability in relaying an unadulterated text and justifies his confidence in the gratitude with which the beneficial publication of the stolen Commentaires will be received.

This editorial confidence is precisely echoed by Agrippa d'Aubigné, who similarly presents Les Tragiques as stolen from an anonymous author equally afraid of publishing his work. D'Aubigné renames his book thief, replacing Flavius with the "larron Promethee," who fears no punishment for his theft or publication but boldly rewrites a criminal act requiring pardon as an act of charity to be endorsed:

\begin{abstract}
Voici le larron Promethee, qui, au lieu de grace, demande gré de son crime, et pense vous pouvoir justement faire present de ce qui n'est pas à luy, comme ayant desrobé pour vous ce que son maistre vous desroboit, à soy-mesme, et qui plus est, ce feu que j'ay volé mouroit sans air; c'estoit un flambeau sous le muy, mon charitable peché l'a mis en evidence: je dis charitable à vous et à son autheur. ${ }^{83}$
\end{abstract}

The poetic justice of successfully stealing from a thief, or from an author unjustly depriving the reading public of Les Tragiques, and so restoring knowledge to the public domain, recalls both Erasmus's proverb and his conception of an intellectual commonwealth, to which valuable knowledge belongs and from which it should not be withheld. D'Aubigné finds biblical authority for this idea in the parable of the light under the bushel (Matthew 5:15); classical mythology

83. Agrippa d'Aubigné, Les Tragiques, in Euvres, ed. Henri Weber, Jacques Bailbé, and Marguerite Soulié (Paris: Gallimard, 1969), 3. This re-writing is programmatic of d'Aubigné's new interpretation of familiar events in Les Tragiques. Prometheus is generally represented positively in the Renaissance: poets tend to focus upon his suffering not as punishment, but as an image for the pains typically of love. See Trousson, 1:83-141 (esp. 139). 
(Prometheus), Roman legal history (Flavius), and biblical authority (Matthew) thus combine to endorse not only an editorial book thief but also the publication of the fruits of his theft.

D'Aubigné's theft is of course a fiction: it serves as a dramatic emphasis of the value of Les Tragiques, comparable to Prometheus's gift of fire or Flavius's gift of access to justice, as historical truth is metaphorically stolen from oblivion by the chronicler recording it and so preserving it in time. Similarly, if La Place was as familiar with Pliny as he was with Pomponius, then perhaps the analogy with Flavius and a complicit Appius quietly indicates that he was more involved with the publication of the Commentaires than the prefatory material implies. Where Coustau and Mignault, developing Erasmus's emphasis on the respect due to ancient authorities, use "cornicum oculos configere" to warn against poetic and theological mysteries being reinterpreted by and disseminated to the uninitiated, d'Aubigné and La Place express unreserved confidence in their qualification to undertake the task at hand, in its benefits to their readers, and in the value of the intellectual theft and publication that the proverb and Flavius represent.

\section{Conclusion}

Erasmus's Adages represents a turning-point in the reception history of Flavius and of his theft and publication of the law. Ancient ambivalence towards the cunning displayed by Flavius and epitomized by "cornicum oculos configere" persists in the Renaissance. However, ancient judgments of Flavius's theft are chiefly influenced by attitudes to authority, leading Livy and Valerius to criticize his social presumption but prompting Cicero, Pliny, and Pomponius to celebrate his reappropriation of publicly beneficial information from the exclusive possession of the pontiffs. In contrast, and in the wake of Erasmus, Renaissance reactions to Flavius remain mixed, but on epistemological rather than authoritarian grounds. While Flavius's intellectual theft is welcomed by Budé and Coustau as an exemplary metaphor for the transfer of valuable (legal) knowledge, it is also subject to caution: humanist anxiety about the degradation of scholarship through unauthorized publications prompts Mignault and Coustau to qualify who is entitled to participate in the dissemination of stolen knowledge. 
Yet this very qualification in itself helps cement the idea that knowledge may be stolen: La Place's late and unconditional championing of Flavius is of a publisher and, primarily, a thief. Even the supplanting of Flavius, by Coustau and by d'Aubigné, with his replacement Prometheus confirms his association with an increasingly positive representation of theft: Flavius represents theft and reward, even if his actions provoke anxiety; in contrast, Prometheus represents theft and punishment, but comes to be celebrated for his heroism in Renaissance France. The ready acceptance of the idea of Flavius's actions as intellectual theft implies a recognition of the concept of intellectual property, allied, again in the wake of Erasmus, to a strong belief that ownership of such property should often, but not quite always, be common. None of the anxiety that Flavius provokes is prompted by his theft; it is a response to unauthorized publication, celebrated in his example but perhaps to be regretted elsewhere.

For the caveats surrounding the proverb and Flavius all relate not to the act of publication per se, but to the dangers of a lack of discrimination, qualification, or discernment; unregulated publication, like unqualified open access, risks a proliferation of the poor commentaries that Erasmus, Budé, Mignault, and Coustau all decry. In response, the humanist project reverts to leading by example, promoting the proper acquisition and transfer of knowledge through diligent study and qualified publication. In the process, it hopes to demonstrate the proverb in action in its most positive sense, matching like not quite with like but with a superior equivalent whose clear scholarly credentials establish its own authority and displace poor imitations. Open access may threaten scholarship with a loss of quality control, as freedom of publication indiscriminately encourages readers to feel qualified to write and get published. Yet open access also guarantees a wide readership for scholarship whose quality has already been assured. Crows' eye piercing in its finest sense thus expands the bounds of the Republic of Letters and paves the way for the greater scholars of the future, still to come. 